\title{
How a teacher professional development program influences students' algebra performance? Reflections from a web-based platform
}

\author{
Dilek Tanışl1 ${ }^{1}$, Handegül Türkmen ${ }^{2}$, Melih Turgut ${ }^{3}$ and Nilüfer Köse ${ }^{4}$ \\ ${ }^{1}$ Anadolu University, Faculty of Education, Turkey (ORCID: 0000-0002-2931-5079) \\ ${ }^{2}$ Ministry of National Education, Turkey (ORCID: 0000-0003-4129-6816) \\ ${ }^{3}$ Norwegian University of Science and Technology, Norway (ORCID: 0000-0003-3777-9882) \\ ${ }^{4}$ Anadolu University, Faculty of Education, Turkey (ORCID: 0000-0001-7407-7498)
}

\begin{abstract}
The main purpose of this study was to assess seventh-graders' algebra performance when their teachers received professional development support regarding hypothetical learning trajectories through a webbased platform. Secondly, we aimed to investigate the relationship between student performance and the teachers' professional development in teaching algebra. A mixed-method research paradigm was adopted into the study. Experimental research was conducted with nine experimental and nine control groups including 454 seven graders. The data came from a combined algebra (including open-ended and multiple-choice tasks) test and experimental group teachers' teaching designs where the plans were entered to the web-based platform. Statistical methods were used to analyse the quantitative data, while descriptive methods were used to analyse the qualitative data. The results revealed that the experimentalgroup students (whose teachers received professional development support through the web-based platform) statistically outperformed compared to those in control groups. Besides, a relationship between was found between the experimental group teachers' progress and algebra performance of their students.
\end{abstract}

Keywords: Teaching algebra; Professional development; Mathematics teachers; Middle school students; Hypothetical learning trajectory

Article History: Submitted 19 July 2020; Revised 1 November 2020; Published online 20 November 2020

\section{Introduction}

Studies have revealed that students have difficulties in understanding the basic concepts of algebra and have misconceptions throughout their school life (Carraher, Schliemann, \& Brizuela, 2005; Falkner, Levi \& Carpenter, 1999, Stephens, 2008), and issues still apparent in the recent studies (Barbieri, Miller-Cotto \& Booth, 2019; Mokh, 2019; Zielinski, 2017). According to Akkan, Baki \& Çakıroğlu (2011), one of the main reasons for student difficulties is a cognitive gap possibly due to the rapid transition from the context of arithmetic to algebra. On the other hand, researchers claim as a central issue about algebra is its epistemological structure, especially its semantic aspect, that is, interpreting the meanings of algebraic symbols and concepts (e.g. Thomas \& Tall, 2001).

Address of Corresponding Author

Dilek Tanışlı, PhD., Anadolu University, Department of Mathematics and Science Education, 26470 Tepebaşı/Eskişehir, Turkey.

$\triangle$ dtanisli@anadolu.edu.tr

How to cite: Tanişli, D., Türkmen, H., Turgut, M., \& Köse, N. (2020). How a teacher professional development program influences students' algebra performance? Reflections from a web-based platform. Journal of Pedagogical Research, 4(3), 327-343. 
To overcome such a central issue, there is a need for an effective algebra instruction which emphasizes the semantic aspect of algebra. While planning this teaching, teachers' preparation and implementation of activities which consider student's prior knowledge and misconceptions, and also the paths they could follow could support semantic learning. In this process, teachers need to use teaching models that are in line with students' mathematical thinking. One of the teaching models that take student thinking into account is the theoretical framework called the Hypothetical Learning Trajectory (HLT). The notion of HLT can be an effective tool to understand students' misconceptions, strategies, thinking and hypothesized learning paths regarding a mathematical concept (Simon, 1995). In this respect, the following main question arises: Can we use HLT as a heuristic tool for the professional development of mathematics teachers? Concerning this, there have appeared several studies in the literature that support the contribution of HLT to the development of both teachers' professional and students' learning levels (Simon \& Tzur, 2004; Wilson, Mojica \& Confrey, 2013; Wright, 2014). In these studies, it was pointed out that the programs prepared within the framework of HLT contributed to the professional development of teachers; that at the end of the program, their knowledge about the evaluation of their students increased by focusing on their mathematical thoughts; and that the teachers could make effective use of their mathematics teaching knowledge to direct their teaching process at times when their students had difficulty (Mojica, 2010; Wilson et.al., 2013). In the present paper, we consider HLT as a professional development tool as a part of the project to contribute teachers to design effective algebra teaching environments.

\subsection{The Project and Research Questions}

In Turkey, professional development activities for in-service teachers are formally held by the Ministry of National Education. Also, a limited number of teachers contribute to their professional development by taking post-graduate education or participating in various studies (i.e. projects) organized by universities. However, it can be addressed two major issues (Y1ldırım, 2013) in such activities: lack of sustainable professional development programs and the gap between research and practice. Following the gap between research and practice, we prepared a large-scale project titled Supporting the Professional Development of Middle School Mathematics Teachers with a Web-Based System. The main purpose of the project was to support the professional development of lower secondary mathematics teachers. We aim to design a web-based platform - (so-called MEGEDEP) - to provide an environment where the teachers design their HLTs step - by - step by communicating, discussing and receiving mathematics teacher educators' feedback. In other words, MEGEDEP has created a context where the mathematics teachers and mathematics teacher educators could communicate and collaborate to design, revise, implement teaching plans and upload or write reflections after teaching episodes (for the details regarding the project, please see Tanışl1, Ayber, Köse, and Turgut (2018) and Tanışl1, Köse, and Turgut (2019)).

The most important factor of teachers' professional development is considering students thinking and learning in designing teaching. In the present paper, we focus on seven graders' algebra performance, how their performance has changed after their teachers have designed and implemented HLTs by communicating mathematics teacher educators. Adopting experimental research, we focused on the effectiveness of teachers' design of hypothetical learning trajectories on seven graders algebra performance on the one hand and aimed to present the link between mathematics teachers' progress on teaching algebra and students' algebra performance on the other. We focus on the following two main research questions:

1. What is the effect of HLT based (which designed through the MEGEDEP) teaching on seven graders' algebra performance?

2. What is the development level of mathematics teachers after MEGEDEP use and what the relationship between teachers' progress and their students' algebra performance?

This study differs from other studies in literature in terms of revealing the professional development of the teachers who received training via MEGEDEP, which was prepared based on 
the notion of HLT, as well as revealing the influence of their professional development on their students' algebra performance. The results of the study could contribute to mathematics education literature concerning both overcoming the problems in algebra and introducing a web-based education platform based on HLT as a professional development tool.

\subsection{Theoretical Framework}

In this work, we considered the notion of Hypothetical Learning Trajectory (HLT) as a theoretical framework. This notion was first introduced by Simon (1995). Indeed, HLT was defined as a component of the Mathematics Teaching Cycle (MTC), which considers teaching mathematics in a large context. For example, in this cycle, the teacher's knowledge and assessment of student learning were also included. Figure 1 summarizes HLT and other associated components regarding mathematics teaching cycle.

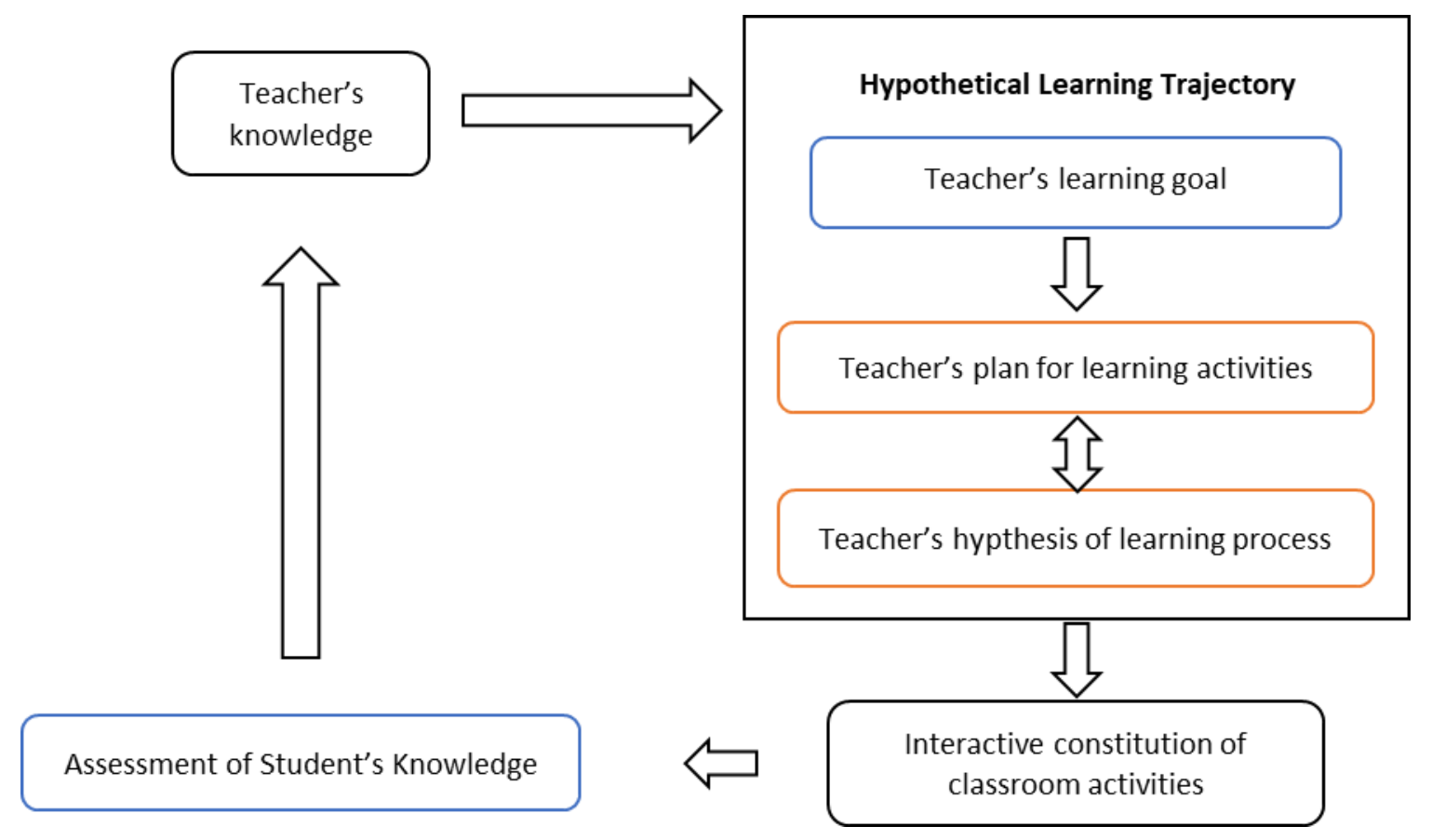

Figure 1. MTC and HLT (adopted from Simon, 1995, p. 136)

Simon (1995) bases about the determination of the learning goal or lesson design on the following two interrelated factors: (1) Teacher's mathematical knowledge and (2) teacher's hypothesis about his/her student's knowledge. In other words, the teacher should have the mathematical knowledge behind the subject that he/she sets while determining the learning goal. At the same time, the learning goal determined by the teacher must be appropriate to the prior knowledge of the audience (Zembat, 2016).

Simon (1995) underlined that teacher's mathematics knowledge and prediction of student knowledge could help the teacher while specifying and determining the learning goal. Also, it was pointed out that the teacher's knowledge of mathematical activity and representation, theoretical knowledge about mathematics learning and teaching, and knowledge about the student learning will contribute to the development of learning activities and hypothetical learning process. However, HLT does not mean that the teacher always pursues a single goal or thinks about a single and simple path. On the contrary, the goals can be revised continuously (i.e. making observations regarding student knowledge etc.) in HLT, and so can the HLT itself. Here, it is pointed out that it is important to have a goal in HLT and for justification regarding finalizing teaching plan. Mathematical activities, as the second component of HLT, play a key role in the effectiveness of mathematics teaching (Simon \& Tzur, 2004).

Simon (1995) stated that the development of the hypothetical learning process and the development of learning activities have a mutual relationship. The researcher linked the formation 
of ideas for the learning activities to the teacher's assumptions about the development of students' thinking and learning. Simon (1995) expressed the third component of HLT as teachers' assumptions about how student thinking and understanding will change within the context of activities. In this respect, while planning the lesson, the teacher should put forward hypotheses about how students can learn the desired subjects and about what kind of problems may arise in this process (Zembat, 2016).

Why we adopted HLT perspective as a professional development tool was based on the teacher's content and pedagogical knowledge. As a combined view, indeed, the notion of Pedagogical Content Knowledge (PCK) was first introduced by Shulman (1986) as specific knowledge types that teachers should have. As Shulman addresses, teachers need advanced knowledge as the intersection of pedagogical knowledge and content knowledge. Based on Shulman's framework, many researchers have tried to conceptualize teachers' mathematics teaching knowledge (Even \& Ball, 2009; Neubrand, 2018; Rowland, Huckstep \& Thwaites, 2005; Ball, Thames \& Phelps, 2008). There are many perspectives on PCK, however, two components are forefront in the recent studies (Goos, 2020; Hurst, 2016): content knowledge and pedagogical knowledge. Therefore, we based HLT to support the professional development of mathematics teachers since the model (in Figure 1) considers both the teacher's knowledge and designing classroom activities according to students' needs/pre-knowledge to create meaningful algebra environment.

\section{Methods}

In this study, a mixed-method research paradigm was adopted as a combination of quantitative and qualitative research methods. Following research questions, we adopted "the convergent parallel design" (Creswell, 2011, p. 540), which enabled us to collect quantitative and qualitative data synchronously and to analyse separately. At the end of the analyses, we compared and contrasted all findings. Figure 2 summarizes our convergent parallel design in the present study.

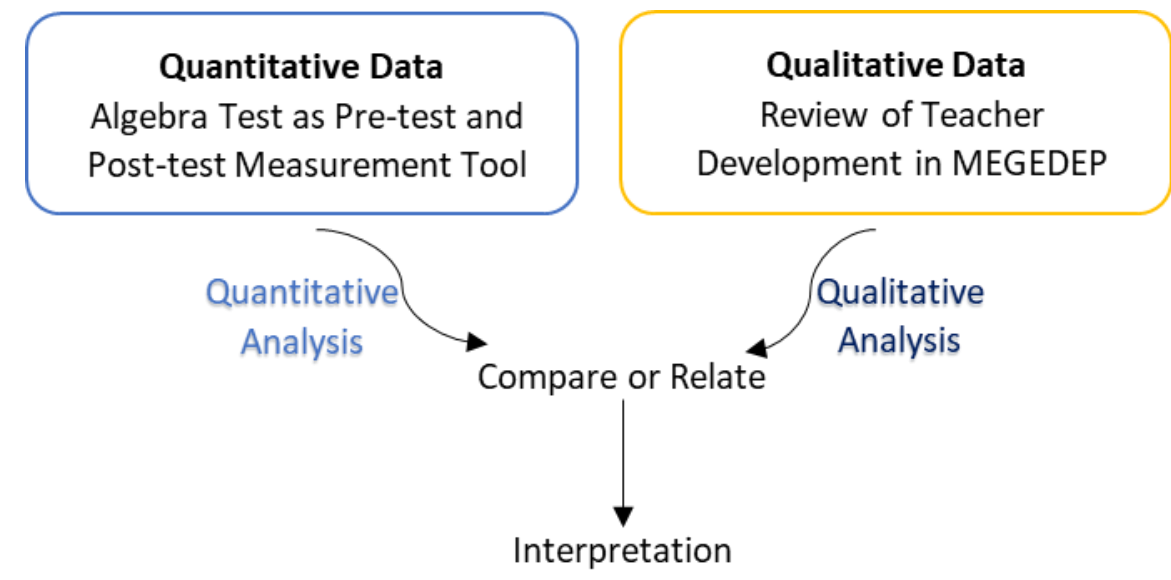

Figure 2. Adopted Convergent Parallel Design

In the present research, the experimental research model was used within the scope of the quantitative research approach. To respond to the first research question, the study was conducted using the quasi-experimental design as a pre-test-post-test experimental design with the control group. To explore the second research question, a basic qualitative research design was used. This approach allows discovering and understanding a phenomenon, a process or understandings indepth (Creswell, 2011).

\subsection{Study Group and Procedure}

As the participants of the study, 9 teachers $\left(\mathrm{T}_{1}, \mathrm{~T}_{2}, \mathrm{~T}_{3}, \mathrm{~T}_{4}, \mathrm{~T}_{5}, \mathrm{~T}_{6}, \mathrm{~T}_{7}, \mathrm{~T}_{8}, \mathrm{~T}_{9}\right)$ were selected randomly among 30 volunteering in-service mathematics teachers who were teaching at state secondary schools and who participated in the project. The volunteering teachers completed all the phases of 
the four-task cycle specified in the web-based - MEGEDEP - system. In the task cycle, the processes that the teachers would go through while creating and implementing the learning trajectories (creating the learning goals, preparing the lesson plan, applying the lesson plan and adding the lesson video) were designed cyclically. A moderator was appointed to give feedback to all three teachers. In this process, each teacher determined learning goals based on their inferences regarding their students' understandings in line with the curriculum competencies and then prepared HLT with the guidance of the moderators with hypotheses and predictions about how the learning would progress. They created lesson plans including learning activities regarding HLT. Teachers were provided feedbacks by the relevant moderator about each process completed in the process of creating a learning trajectory, preparing a lesson plan and implementing the plan. At the same time, reflection questions were asked twice to the teachers about the process. After the teachers answered the reflection questions, the moderator evaluated and approved the process, and the teacher moved onto the next process.

The teachers who completed their task cycles applied the plans they prepared to seventh-grade students at the schools where they worked. Thus, the data were collected from 454 seventh-grade students.

To assign control and experimental groups at (eight different) schools, the Algebra Test, whose validity and reliability studies were carried out before, was applied to different classes. We assigned classes of the participant teachers as the experimental groups, while nine control groups were assigned from different schools according to descriptive statistical analyses. According to the results, 18 classes were paired and coded as follows: Class $_{i}-$ Class $_{j}$, where Class $_{i}$ is a control group and $i$ is an odd number, while Class $\mathrm{j}_{\mathrm{j}}$ is an experimental group and $j$ is an even number.

\subsection{Algebra Test}

In the study, the Algebra Test was used as a quantitative data collection tool to determine algebra performance of the students. The validity and reliability studies of this data collection tool were conducted with a pilot application (Tanışl1, Ayber \& Turgut, 2018) with 175 seven-graders. Algebra Test included a combination of multiple-choice tasks and open-ended tasks. Exemplary tasks of Algebra Test are expressed in Table 1.

Table 1

Exemplary tasks from Algebra Test

\section{Multiple-Choice Task}

7. $x+y+z=x+p+z$

For the above equality, which of the following statements is always true?

A) This equation is true for any value to be assigned to $\mathrm{x}, \mathrm{y}, \mathrm{z}$ and $\mathrm{p}$.

B) This equation is true for any value to be assigned to $x, y, z$ and $p$.

C) $y$ and $p$ being equal; this equation is true for any value to be assigned to $x, y, z$ and $p$.

D) This equation is true only for one value to be assigned to $\mathrm{x}, \mathrm{y}, \mathrm{z}$ and $\mathrm{p}$.

E) This equation is true for the values of $x=-3, y=-$ $2, \mathrm{z}=1, \mathrm{p}=2$.

12. Which of the following is equal to

$(10 a-5)-(-2 a-7)$ ?
A) $8 a-12$
B) $8 a+2$
C) $12 a-12$
D) $12 a+2$

\section{Open-ended Task}

2. Ayhan gave me a certain amount of money. Which one is bigger:

an amount 3 times more than the money given by Ayhan or

an amount 6 Lira more than the money given by Ayhan?

Please explain your claims in detail.

3. The number of candies in a box is $x$. Melih has 2 boxes. Kübra has 3 times more candies than Melih. How many candies does Kübra have?

Please explain. 
After validity and reliability studies, Cronbach's alpha was .84 and tetrachoric factor analyses confirmed single factor structure with acceptable index values (i.e. $\mathrm{KMO}=.81$, GFI $=.92$ ). The final version of the Algebra Test included 22 multiple choices items and 5 open-ended tasks.

\subsection{Quantitative Data Analysis}

Algebra performance of the students was calculated by the sum of students' correct answers to each multiple-choice task and scores come from open-ended tasks. To analyse open-ended tasks, the following rubric was based (Table 2).

Table 2

Rubric to analyse open-ended tasks

\begin{tabular}{ll}
\hline Score & Criterion \\
\hline $\mathbf{0}$ & No answer or wrong \\
$\mathbf{1}$ & Very limited explanation or solution \\
$\mathbf{2}$ & The explanation or the solving process is clear, but with no complete answer \\
$\mathbf{3}$ & The explanation and the solving process is correct, but with a slight error, \\
$\mathbf{4}$ & omission or uncertainty \\
\hline
\end{tabular}

An example can be given regarding the function of the rubric above. See the solution in the Figure 3. The student correctly expressed the multiplicative relationship between the quantities given in the problem by transforming a verbal statement into an algebraic statement. To put it more clearly, the student represented the number of unknown candies in a box with the $x$ and showed the total candies of Melih with $2 x$ algebraic expression. S/he also wrote the equation 3. $(2 x)=6 x$ by establishing the multiplicative relationship between Kübra's candies and Melih's number of candies. He stated that the $6 x$ algebraic expression in this equation also represents the number of candies of Kübra. It was evaluated with 4 points because it gave a full correct answer.

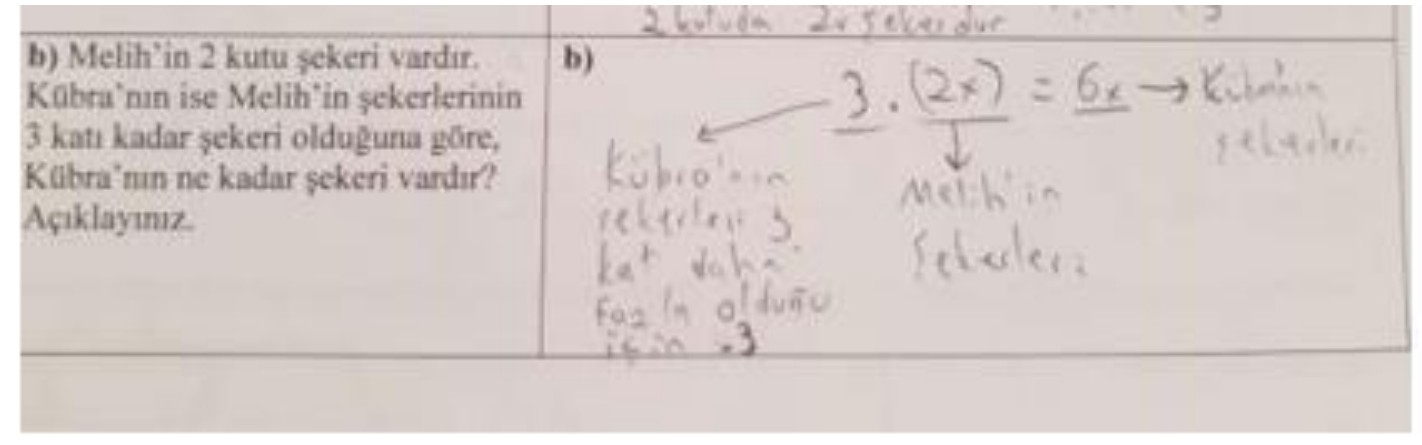

Task: (The number of candies in a box is $x$ ). Melih has 2 boxes. Kübra has 3 times more candies than Melih. How many candies does Kübra have?

(Translated)

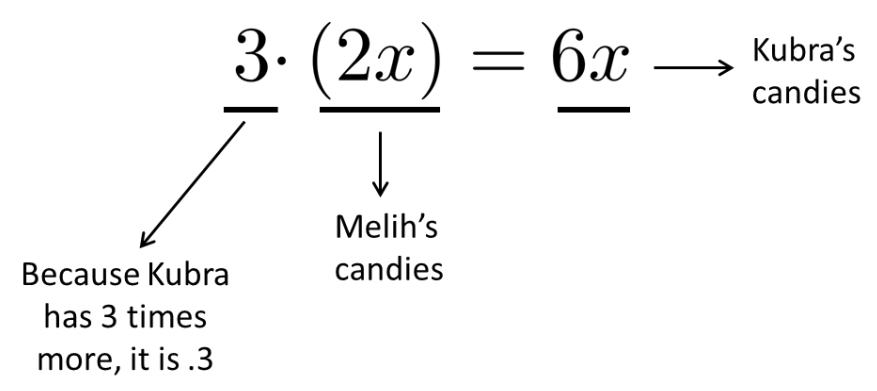

(Translated)

Figure 3. Exemplary Student Solution and the use of Rubric

In the same question, another student wrote the multiplicative relationship between the sugar number of Kübra and the sugar number of Melih as 3.(2x) by expressing the sugar number of Melih as 2x. This student's failure to specify Kübra's sugar count was considered as an incomplete answer and 3 points were given to this student's answer. 
Total scores of each class were transferred to SPSS 21.0 package software. First, Shapiro-Wilk analysis was used to see if the data sets were distributed normally or not. This followed parametric (independent samples t-test, related-samples t-test) and non-parametric (Mann Whitney U test, Wilcoxon Signed Ranks test) techniques with the significance level .05.

\subsection{Qualitative Data Analysis}

Regarding the second research question, to determine the levels of the teachers as a result of their progress (who completed their task cycles in MEGEDEP), three levels were created by comparing their work in the first and fourth weeks. Below (Table 3) are the levels and related characteristics.

Table 3

Assigned Teacher Levels and Associated Characterizations

\begin{tabular}{ll}
\hline Level & Characterization \\
\hline Advanced & $\begin{array}{l}\text { Teachers at this level determine the learning goal in line with the given } \\
\text { curriculum competencies and generate hypotheses about the learning progress } \\
\text { of their students. They ask specific questions to students to reveal student } \\
\text { thinking. }\end{array}$ \\
\hline $\begin{array}{l}\text { Upper- } \\
\text { Intermediate }\end{array}$ & $\begin{array}{l}\text { Teachers at this level determine the learning goal in line with the given } \\
\text { curriculum competencies and generate hypotheses about the learning progress } \\
\text { of their students. However, they ask partly thought-provoking questions to } \\
\text { reveal the student thinking. }\end{array}$ \\
\hline Intermediate & $\begin{array}{l}\text { The teachers at this level determine the learning goal appropriate to the given } \\
\text { curriculum competencies. However, they do not generate hypotheses about the } \\
\text { learning progress of their students; they experience the learning-teaching } \\
\text { confusion and point to the order they will follow in their teaching rather than } \\
\text { to the learning progress. To reveal the student thinking, they ask questions that } \\
\text { also include the answers. }\end{array}$
\end{tabular}

While forming the levels in Table 3 and assigning the teachers to the levels, two field experts in mathematics and a researcher (math teacher) worked on the data independently. They analysed teachers and assigned a level and then came together to compare their findings. Reliability of $92 \%$ was achieved as a result of the coders' agreement (Miles \& Huberman, 1994).

\section{Results}

\subsection{Comparing Students' Algebra Performance}

To explore the first research question, normal distribution analyses were conducted for each paired group. In this way, whether a parametric or non-parametric test would be used was decided. Concerning this, the results of the normality analyses can be seen in Table 4 .

According to Table 4, the post-test scores of the control and experimental classes in Group1, Group2, Group3, Group8 and Group9 were normally distributed ( $>>$.05). Therefore, independent samples t-test was used to compare algebra performances of control and experimental classes. Table 5 presents the independent samples t-test results of the post-test scores.

According to Table 5, the algebra performance of the Group1 students did not differ concerning the control and experimental groups $(\mathrm{t}=1.14, \mathrm{p}>.05)$. It could be stated that the MEGEDEP applications did not have a positive impact on the students' algebra performance in Class2. However, the algebra performance of the students in the experimental classes in Group2 $(\mathrm{t}=-3.04$, $\mathrm{p}<.05)$, Group3 $(\mathrm{t}=-3.17, \mathrm{p}<.05)$, Group8 $(\mathrm{t}=-2.10, \mathrm{p}<.05)$ and Group9 $(\mathrm{t}=-2.72, \mathrm{p}<.05)$ were significantly higher than in control groups. According to these findings, generally, the teaching plans that designed on MEGEDEP had positive effects on the students' algebra performance in the normally distributed groups. 
Table 4

Shapiro-Wilk Normality Analysis Results of the Post-Test Scores of the Classes

\begin{tabular}{|c|c|c|c|c|c|c|}
\hline \multirow[b]{2}{*}{$\begin{array}{l}\text { Group } \\
\text { Code }\end{array}$} & \multirow[b]{2}{*}{ Class Code } & \multirow[b]{2}{*}{$\overline{\mathbf{X}}$} & \multirow[b]{2}{*}{ SD } & \multicolumn{3}{|c|}{ Shapiro-Wilk } \\
\hline & & & & Statistics & df & $\mathbf{P}$ \\
\hline \multirow[t]{2}{*}{ Group1 } & \multirow{2}{*}{$\begin{array}{l}\text { Class1 (Control) } \\
\text { Class2 (Experimental) }\end{array}$} & 79.64 & 20.32 & .964 & 26 & .480 \\
\hline & & 85.23 & 15.53 & .972 & 26 & .677 \\
\hline \multirow[t]{2}{*}{ Group2 } & \multirow{2}{*}{$\begin{array}{l}\text { Class3 (Control) } \\
\text { Class4 (Experimental) }\end{array}$} & 67.05 & 12.52 & .982 & 18 & .972 \\
\hline & & 81.44 & 16.49 & .966 & 18 & .712 \\
\hline \multirow[t]{2}{*}{ Group3 } & Class5 (Control) & 46.30 & 15.72 & .991 & 23 & .998 \\
\hline & Class6 (Experimental) & 61.50 & 17.51 & .971 & 23 & .708 \\
\hline \multirow[t]{2}{*}{ Group4 } & Class7 (Control) & 90.72 & 15.59 & .963 & 32 & .337 \\
\hline & Class8 (Experimental) & 101.03 & 11.71 & .921 & 32 & .022 \\
\hline \multirow[t]{2}{*}{ Group5 } & Class9 (Control) & 38.37 & 14.97 & .934 & 27 & .087 \\
\hline & Class10 (Experimental) & 61.96 & 27.86 & .906 & 27 & .018 \\
\hline \multirow[t]{2}{*}{ Group6 } & Class11(Control) & 84.27 & 21.75 & .838 & 20 & .003 \\
\hline & Class12 (Experimental) & 83.40 & 15.54 & .915 & 20 & .080 \\
\hline \multirow[t]{2}{*}{ Group7 } & Class13(Control) & 85.96 & 22.98 & .920 & 29 & .030 \\
\hline & Class14 (Experimental) & 105.54 & 6.78 & .976 & 29 & .728 \\
\hline \multirow[t]{2}{*}{ Group8 } & Class15(Control) & 56.30 & 15.46 & .940 & 22 & .202 \\
\hline & Class16 (Experimental) & 65.72 & 14.52 & .957 & 22 & .437 \\
\hline \multirow[t]{2}{*}{ Group9 } & Class17(Control) & 63.09 & 14.04 & .919 & 21 & .081 \\
\hline & Class18 (Experimental) & 76.30 & 17.74 & .955 & 21 & .424 \\
\hline
\end{tabular}

df: Degree of freedom, Sd: Standard Deviation

Table 5

Independent Samples t-test Results of Post-test of Normally Distributed Groups

\begin{tabular}{|c|c|c|c|c|c|c|c|}
\hline $\begin{array}{l}\text { Group } \\
\text { Code }\end{array}$ & Class Code & $\mathbf{N}$ & $\overline{\mathbf{X}}$ & Sd & $\mathbf{t}$ & df & $\mathbf{p}$ \\
\hline \multirow[t]{2}{*}{ Group1 } & Class1 (Control) & 31 & 79.64 & 20.32 & \multirow[t]{2}{*}{1.14} & \multirow[t]{2}{*}{55} & \multirow[t]{2}{*}{.256} \\
\hline & Class2 (Experimental) & 26 & 85.23 & 15.53 & & & \\
\hline \multirow[t]{2}{*}{ Group2 } & Class3 (Control) & 20 & 67.05 & 12.52 & \multirow[t]{2}{*}{-3.04} & \multirow[t]{2}{*}{36} & \multirow[t]{2}{*}{.004} \\
\hline & Class4 (Experimental) & 18 & 81.44 & 16.49 & & & \\
\hline \multirow[t]{2}{*}{ Group3 } & Class5 (Control) & 23 & 46.30 & 15.72 & \multirow[t]{2}{*}{-3.17} & \multirow[t]{2}{*}{47} & \multirow[t]{2}{*}{.003} \\
\hline & Class6 (Experimental) & 26 & 61.50 & 17.51 & & & \\
\hline \multirow[t]{2}{*}{ Group8 } & Class15 (Control) & 23 & 56.30 & 15.46 & \multirow[t]{2}{*}{-2.10} & \multirow[t]{2}{*}{22} & \multirow[t]{2}{*}{.041} \\
\hline & Class16 (Experimental) & 22 & 65.72 & 14.52 & & & \\
\hline \multirow[t]{2}{*}{ Group9 } & Class17 (Control) & 21 & 63.09 & 14.04 & \multirow[t]{2}{*}{-2.72} & \multirow[t]{2}{*}{42} & \multirow[t]{2}{*}{.009} \\
\hline & Class18 (Experimental) & 21 & 76.30 & 17.74 & & & \\
\hline
\end{tabular}

When Table 4 was examined, it can be seen that the post-test scores of Class7, Class9, Class12 and Class14 were normally distributed ( $p>.05)$, while the post-test scores of the Class8, Class10, Class11 and Class13 were not normally distributed $(p<.05)$. Therefore, to analyse the post-test scores, Mann-Whitney U test was used for the comparison of the two classes in Group4, Group5, Group6 and Group7. The results of the Mann-Whitney U test can be seen in Table 6. 
Table 6

Mann-Whitney U test Results Regarding the Post-test Scores of Non-Normally Distributed Groups

\begin{tabular}{|c|c|c|c|c|c|c|}
\hline $\begin{array}{l}\text { Group } \\
\text { Code }\end{array}$ & Class Code & $\mathbf{N}$ & $\begin{array}{l}\text { Mean } \\
\text { Rank }\end{array}$ & $\begin{array}{c}\text { Sum of } \\
\text { Ranks }\end{array}$ & $\mathbf{U}$ & $\mathbf{p}$ \\
\hline \multirow{2}{*}{ Group4 } & Class7 (Control) & 33 & 18.24 & 601.92 & \multirow{2}{*}{1015.00} & \multirow[t]{2}{*}{.000} \\
\hline & Class8 (Experimental) & 32 & 48.22 & 1543.04 & & \\
\hline \multirow{2}{*}{ Group5 } & Class9 (Control) & 27 & 17.50 & 472.50 & \multirow[t]{2}{*}{634.50} & \multirow[t]{2}{*}{.000} \\
\hline & Class10 (Experimental) & 27 & 37.50 & 1012.50 & & \\
\hline \multirow{2}{*}{ Group6 } & Class11 (Control) & 20 & 22.09 & 485.98 & \multirow[t]{2}{*}{207.00} & \multirow[t]{2}{*}{.743} \\
\hline & Class12 (Experimental) & 20 & 20.85 & 417.00 & & \\
\hline \multirow{2}{*}{ Group7 } & Class13 (Control) & 29 & 22.69 & 658.01 & \multirow[t]{2}{*}{676.00} & \multirow[t]{2}{*}{.001} \\
\hline & Class14 (Experimental) & 31 & 37.81 & 1172.11 & & \\
\hline
\end{tabular}

According to Table 6, the post-test algebra performance in Group4 ( $U=1015.00, p<.001$ ), Group5 ( $\mathrm{U}=634.50, \mathrm{p}<.001)$ and Group7 $(\mathrm{U}=676.00, \mathrm{p}<.05)$ were significant. The post-test scores of Class8 $(\overline{\mathrm{X}}=101.03, \mathrm{Sd}=11.71)$ were higher than those of Class7 $(\overline{\mathrm{X}}=90.72, \mathrm{Sd}=15.59)$; the posttest scores of Class10 ( $\overline{\mathrm{X}}=61.96, \mathrm{Sd}=27.86)$ were significantly higher than those of Class9 $(\overline{\mathrm{X}}=38.37, \mathrm{Sd}=14.97)$; and the post-test scores of Class14 $(\overline{\mathrm{X}}=105.54, \mathrm{Sd}=6.78)$ than those of Class13 $\bar{X}=85.96, S d=22.98)$. According to these results, the algebra teaching carried out by the teacher taking part in MEGEDEP had positive impacts on the students' algebra performance. On the other hand, the algebra performance of Group6 students did not differ concerning the class $(\mathrm{U}=207.00, \mathrm{p}>.05)$. According to this result, the teaching based on the learning trajectories prepared on MEGEDEP - within the context of Group 6 - did not affect the students' algebra performance. Although there was no significant difference between the post-test scores of the students in the control and experimental groups, the post-test scores of the students in the control group $(\bar{X}=84.27, \mathrm{Sd}=21.75)$ were higher than those of the students in the experimental group $(\overline{\mathrm{X}}=83.40, \mathrm{Sd}=15.54)$.

To examine the changes in the students' algebra performance, first, we focus on control groups. Because the pre-test scores of Class1, Class3 and Class5 were normally distributed (See Table 4) and because the pre-test and post-test scores of Class 15 and Class7 were normally distributed, the changes within themselves were examined using single sample t-test. The results can be seen in Table 7.

Table 7

Single sample t-test results regarding the pretest-posttest scores of normally distributed groups

\begin{tabular}{llccccc}
\hline Class & $\mathbf{N}$ & $\overline{\mathbf{X}}$ & $\mathbf{S d}$ & $\mathbf{t}$ & $\mathbf{d f}$ & $\mathbf{p}$ \\
\hline Class1 (pretest) & 31 & 57.80 & 18.87 & 7.85 & 30 & $\mathbf{. 0 0 0}$ \\
Class1 (posttest) & 31 & 79.64 & 20.32 & & & \\
\hline Class3 (pretest) & 20 & 47.10 & 13.90 & -5.87 & 19 & $\mathbf{. 0 0 0}$ \\
Class3 (posttest) & 20 & 67.05 & 12.52 & & & \\
\hline Class5 (pretest) & 23 & 34.47 & 11.13 & -4.01 & 22 & $\mathbf{. 0 0 1}$ \\
Class5 (posttest) & 23 & 46.30 & 15.72 & & & \\
\hline Class7 (pretest) & 33 & 67.15 & 13.44 & -8.69 & 32 & $\mathbf{0 0 0}$ \\
Class7 (posttest) & 33 & 90.72 & 15.59 & & & \\
\hline Class15 (pretest) & 23 & 43.21 & 13.07 & -4.57 & 22 & $\mathbf{0 0 0}$ \\
Class15 (posttest) & 23 & 56.30 & 15.46 & & & \\
\hline
\end{tabular}

According to Table 7, the significances were in favour of the post-test scores: namely Class1 $(\mathrm{t}=7.85, \mathrm{p}<.05)$, Class3 $(\mathrm{t}=-5.87, \mathrm{p}<.05)$, Class $5(\mathrm{t}=-4.01, \mathrm{p}<.05)$, Class $7(\mathrm{t}=-8.69, \mathrm{p}<.001)$ and Class $15(\mathrm{t}=-4.57, \mathrm{p}<.001)$. On the other hand, the Wilcoxon Signed-Ranks Test was used to examine the 
progress of the groups because the pre-test values of Class9 and Class17 were not normally distributed even the post-test scores were normally distributed. Table 8 presents the results.

Table 8

Wilcoxon Signed-Ranks Test Results Regarding the Pre-Test and Post-Test Scores of Groups 5, 6,7 and 9

\begin{tabular}{|c|c|c|c|c|c|c|c|}
\hline $\begin{array}{l}\text { Group } \\
\text { Code }\end{array}$ & $\begin{array}{l}\text { Class } \\
\text { Code }\end{array}$ & & $\mathbf{N}$ & $\begin{array}{l}\text { Mean } \\
\text { Rank }\end{array}$ & $\begin{array}{l}\text { Sum of } \\
\text { Ranks }\end{array}$ & $\mathbf{Z}$ & $\mathbf{p}$ \\
\hline \multirow{2}{*}{ Group5 } & \multirow{2}{*}{ Class9 } & Negative Rank & 6 & 13.25 & 79.50 & -2.63 & .008 \\
\hline & & Positive Rank & 27 & 14.21 & 298.50 & & \\
\hline \multirow{2}{*}{ Group6 } & \multirow{2}{*}{ Class11 } & Negative Rank & 2 & 2.50 & 5.00 & -3.94 & .000 \\
\hline & & Positive Rank & 20 & 14.40 & 248.00 & & \\
\hline \multirow{2}{*}{ Group7 } & \multirow{2}{*}{ Class13 } & Negative Rank & 1 & 5.00 & 5.00 & -4.59 & .000 \\
\hline & & Positive Rank & 28 & 15.36 & 430.00 & & \\
\hline \multirow{2}{*}{ Group9 } & \multirow{2}{*}{ Class17 } & Negative Rank & 0 & 0 & 0 & -4.01 & .000 \\
\hline & & Positive Rank & 21 & 11.00 & 231.00 & & \\
\hline
\end{tabular}

According to Table 8, the algebra performance of the students in Class9 $(\mathrm{z}=-2.63, \mathrm{p}<.05)$, Class11 ( $\mathrm{z}=-3.94, \mathrm{p}<.001)$, Class13 $(\mathrm{z}=-4.59, \mathrm{p}<.001)$ and Class17 $(\mathrm{z}=-4.01, \mathrm{p}<.001)$ were significant with respect to pre-test and post-test scores. Therefore, the post-test scores of all classes were significant in favour of post-test scores. When we merge the results come from Table 6 and Table 7, in summary, all control groups' algebra performance increased when the (nonparticipating) teachers considered their teaching plans based on the national curriculum.

We now focus on experimental groups. Because pre-test and post-test scores were normally distributed for Class4, Class6, Class12, Class14, Class16 and Class18, we consider related samples t-test. Table 9 shows the results.

Table 9

Related Samples t-test Results Regarding the Pre-Test and Post-Test Scores of Normally Distributed Experimental Groups

\begin{tabular}{|c|c|c|c|c|c|c|}
\hline Class & $\mathbf{N}$ & $\overline{\mathbf{X}}$ & Sd & $\mathbf{t}$ & df & p \\
\hline \multirow{2}{*}{$\begin{array}{l}\text { Class4 (pre-test) } \\
\text { Class4 (post-test) }\end{array}$} & 18 & 45.83 & 7.95 & \multirow[t]{2}{*}{-9.18} & \multirow[t]{2}{*}{17} & \multirow[t]{2}{*}{.000} \\
\hline & 18 & 81.44 & 16.49 & & & \\
\hline \multirow{2}{*}{$\begin{array}{l}\text { Class6 (pre-test) } \\
\text { Class6 (post-test) }\end{array}$} & 26 & 32.50 & 13.75 & \multirow[t]{2}{*}{-10.32} & \multirow[t]{2}{*}{25} & \multirow[t]{2}{*}{.000} \\
\hline & 26 & 61.50 & 17.51 & & & \\
\hline \multirow{2}{*}{$\begin{array}{l}\text { Class12 (pre-test) } \\
\text { Class12 (post-test) }\end{array}$} & 20 & 55.20 & 16.30 & \multirow[t]{2}{*}{-6.06} & \multirow[t]{2}{*}{19} & \multirow[t]{2}{*}{.000} \\
\hline & 20 & 83.40 & 15.54 & & & \\
\hline \multirow{2}{*}{$\begin{array}{l}\text { Class14 (pre-test) } \\
\text { Class14 (post-test) }\end{array}$} & 31 & 65.19 & 13.56 & \multirow[t]{2}{*}{-14.91} & \multirow[t]{2}{*}{30} & \multirow[t]{2}{*}{.000} \\
\hline & 31 & 105.54 & 6.78 & & & \\
\hline \multirow{2}{*}{$\begin{array}{l}\text { Class16 (pre-test) } \\
\text { Class16 (post-test) }\end{array}$} & 22 & 42.54 & 9.73 & \multirow[t]{2}{*}{-8.94} & \multirow[t]{2}{*}{21} & \multirow[t]{2}{*}{.000} \\
\hline & 22 & 65.72 & 14.52 & & & \\
\hline \multirow{2}{*}{$\begin{array}{l}\text { Class18 (pre-test) } \\
\text { Class18 (post-test) }\end{array}$} & 23 & 36.17 & 13.20 & \multirow[t]{2}{*}{-9.17} & \multirow[t]{2}{*}{22} & \multirow[t]{2}{*}{.000} \\
\hline & 23 & 76.30 & 17.74 & & & \\
\hline
\end{tabular}

According to Table 9, the algebra performance of the students in Class4 $(z=-9.18, p<.05)$, Class6 $(\mathrm{t}=-10.32, \mathrm{p}<.05)$, Class12 $(\mathrm{t}=-6.06, \mathrm{p}<.001)$, Class14 $(\mathrm{t}=-14.91, \mathrm{p}<.001)$, Class16 $(\mathrm{t}=-8.94$, $\mathrm{p}<.001)$ and Class18 $(\mathrm{t}=-9.17, \mathrm{p}<.001)$ was significant in favour of post-test results. And Wilcoxon Signed Ranks test was used to compare the pre-test and post-test scores of non-normally distributed classes. Table 10 presents the results. 
Table 10

Wilcoxon Signed Rank Test Results Regarding the Pre-Test and Post-Test Scores of Non-normally Distributed Classes

\begin{tabular}{llccccc}
\hline Class & & $\mathbf{N}$ & Mean Rank & Sum of Ranks & $\mathbf{Z}$ & $\mathbf{p}$ \\
\hline Class2 & Negative Rank & 26 & 0 & 0 & -4.45 & $\mathbf{0 0 0}$ \\
& Positive Rank & 26 & 23.50 & 351.00 & & \\
\hline Class8 & Negative Rank & 0 & 0 & 0 & -4.93 & .000 \\
& Positive Rank & 32 & 16.50 & 528.00 & & \\
\hline Class10 & Negative Rank & 1 & 2.50 & 2.50 & -4.48 & $\mathbf{. 0 0 0}$ \\
& Positive Rank & 26 & 14.44 & 375.50 & & \\
\hline
\end{tabular}

According to Table 10, the algebra performance of the students in Class2 $(z=-4.458, p<.05)$, Class8 $(\mathrm{z}=-4.93, \mathrm{p}<.001)$ and Class10 $(\mathrm{z}=-4.48, \mathrm{p}<.001)$ were significant in favour of post-test results.

In summary, based on these results, it could be stated that the education given by the teachers who designed and implemented the learning trajectories through MEGEDEP had a positive influence on the students' algebra performance. To picture out the change of student performance, Figure 4 is provided.

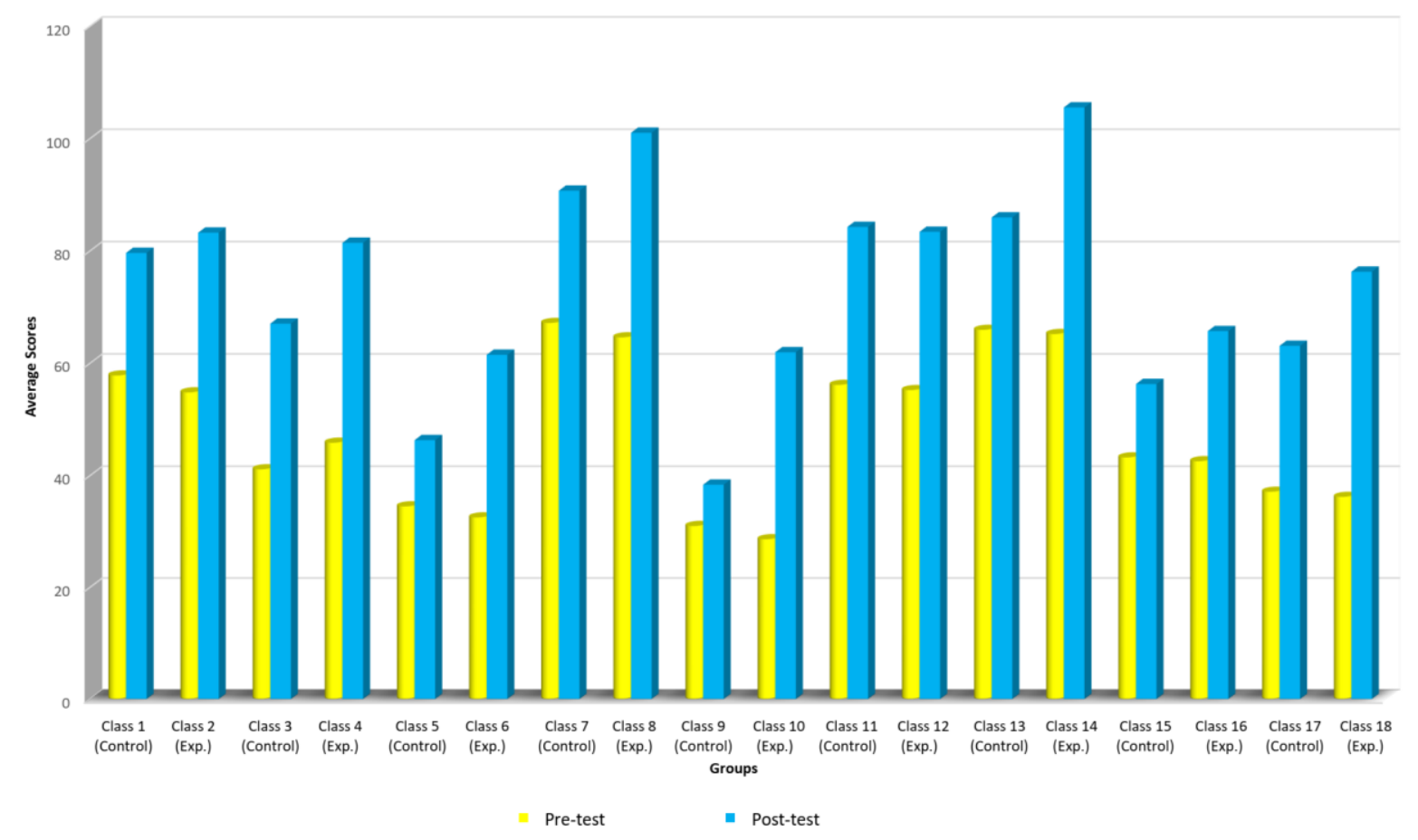

Figure 4. Comparison of the Pretest and Posttest Achievement Scores of the Groups

The graph in Figure 4 shows the pretest-posttest scores of all groups together. As confirming statistical analyses, post-test scores were higher than the pre-test scores in all the experimental and control groups. In the paired groups, except for Group6 (Class 11 and Class 12), the posttest scores of the control group was higher than that of the experimental group.

\subsection{The Link Between Professional Development of Teachers and Students' Algebra Performance}

The teachers participating in the project $\left(T_{1}, T_{2}, T_{3}, T_{4}, T_{5}, T_{6}, T_{7}, T_{8}, T_{9}\right)$ completed their task cycles in four weeks through MEGEDEP platform. Teachers' work in the digital platform was analysed in terms of Table 3 and as a result of this process, the teachers were assigned to the development levels (Table 11). 
Table 11

Teachers' Development Levels After the Use of MEGEDEP Portal

\begin{tabular}{lc}
\hline Levels & Teacher Code \\
\hline $\mathrm{L}_{3}:$ Advanced Level & $T_{2}, T_{5}, T_{6}, T_{7}, T_{9}$ \\
\hline $\mathrm{L}_{2}:$ Upper Intermediate Level & $T_{1}, T_{3}, T_{4}$ \\
\hline $\mathrm{L}_{1}:$ Intermediate Level & $T_{8}$ \\
\hline
\end{tabular}

There were 5 teachers assigned to the advanced level, 3 teachers assigned to the upperintermediate level and 1 teacher assigned to the intermediate level (Table 11). In other words, $55.5 \%$ of the teachers were at an advanced level, 33.3\% were at the upper-intermediate level and $11.1 \%$ were at the intermediate level. To compare teacher development with student performance, we calculated the percentage of the change of algebra test scores. Table 12 shows the results.

Table 12

Teachers' Levels and Percentages of the Change of Algebra Performance

\begin{tabular}{ccll}
\hline Teacher Code & Teachers' Level & Teachers' Class & Change of Algebra Performance \\
\hline$T_{1}$ & $L_{2}$ & Class2 & $\% 55.50$ \\
$T_{2}$ & $L_{3}$ & Class4 & $\% 77.70$ \\
$T_{3}$ & $L_{2}$ & Class6 & $\% 89.20$ \\
$T_{4}$ & $L_{2}$ & Class8 & $\% 56.40$ \\
$T_{5}$ & $L_{3}$ & Class10 & $\% 116.70$ \\
$T_{6}$ & $L_{3}$ & Class12 & $\% 51.08$ \\
$T_{7}$ & $L_{3}$ & Class14 & $\% 61.80$ \\
$T_{8}$ & $L_{1}$ & Class16 & $\% 54.40$ \\
$T_{9}$ & $L_{3}$ & Class18 & $\% 110.90$ \\
\hline
\end{tabular}

When Table 12 is examined, it is seen that the classes of the teachers assigned to the advanced level $\left(\mathrm{L}_{3}\right)$ were generally had the highest progress (Class4, Class10, Class14, Class18) regarding teaching algebra. In parallel to this, the classes of the upper-intermediate level $\left(\mathrm{L}_{2}\right.$; Class 2 and Class8) teachers generally demonstrated less development than advanced level teachers. Class 16 showed the least development among others and the teacher of this class was in the intermediate level group. According to the findings, there was a relationship between the development of the teachers and that of the students of these teachers. In this respect, it was thought that supporting the professional development of the teachers by modelling their learning trajectories was parallel to the increase in the students' algebra performance.

On the other hand, there was a contrary finding of two teachers (T6 and T3) as well. For example, it has been observed that the class (Class12) of the teacher (T6) assigned to $\mathrm{L}_{3}$ is the class with the least improvement. It can be said that the reason for this situation may be due to variables such as the school where the teacher works are in rural areas, the levels of his students are low, and the socio-economic structure of the environment. Another interesting finding is that the teacher assigned to $\mathrm{L}_{2}$ (T3) class (Class6) is one of the most performed classes. The reason for this situation may be that Class6 is in the city centrum and the teacher shows an above-average development.

\section{Conclusion and Discussion}

According to the quantitative findings obtained from the pre-test results, no significant difference between the experimental and control groups was found. This result shows that the students in the experimental and control groups have close knowledge and readiness of the related concepts in the algebra content domain. Considering the pre-test and post-test success scores of each class, it was observed that there was a significant increase in the post-test scores of the students in both the experimental group and the control group compared to the pre-test scores. Since all the students in 
the experimental and control groups went through the algebra teaching process, it can be said that this result is expected. When the achievement scores obtained from the post-tests applied to the experimental and control groups are compared, in seven of the nine paired groups (Group 2, Group 3, Group 4, Group 5, Group 7, Group 8, Group 9), the post-test scores of the students in the experimental group are significantly higher than the post-test scores of the control group students. This situation stems from the received professional development support for experimental groups' teachers. Both previous professional support projects for teachers (Bright, Bowman \& Vacc, 1997; Clarke \& Hollingsworth, 2002) and other studies conducted in recent years argue that there is a strong relationship between teachers professional development and mathematics performance of their students (Akiba \& Liang, 2016; Callaghan, Long, van Es, Reich \& Rutherford, 2018; Prast, van de Weijer-Bergsma, Kroesbergen \& van Liut, 2018).

In one of the groups (Group 1), it was observed that the experimental group students' post-test scores were higher than the control group students' post-test average score, but this high was not statistically significant. When the reasons for this situation were investigated, it was noticed that the control group teacher was a doctoral student continuing his graduate education. The teacher continuing his postgraduate education is an indicator that he continues his professional development. In this case, possibly, the control group teacher may have planned his lessons by using different teaching methods in the teaching process, so that this could be the source of students' algebra performance. At the same time, this result is an indicator that teachers' postgraduate education positively affects the success of students. In this context, it can be said that teachers' postgraduate education is important. In the 2023 Education Vision Document of Turkey (Ministry of National Education [MoNE], 2018), it is seen that a particular emphasis is given to teachers' graduate education.

Regarding Group 6, although there was no significant difference between the post-test scores of the students in the experimental and control groups, it was observed that the post-test scores of the control group students were higher than the post-test scores of experimental group students. When the reasons for this situation were investigated, it was noticed that the control group teacher attended only the seventh-grade classes during the semester. In this case, it is thought that the teacher may have devoted more time to the plans and activities he prepared due to his interest in a single grade level.

Each of the nine teachers participating in the project showed certain levels of progress as a result of the professional development support they received. In line with their progress, it was concluded that five teachers were at a high level (L3), 3 teachers were at upper intermediate level (L2), and 1 teacher was at intermediate level (L1). In line with the findings obtained from the quantitative data, the development levels of the teachers and the improvement in their students' algebra success were related. As a result of this link, it was determined that the students of the teachers who were assigned as advanced level are also showed the most development in algebra performance. Consequently, it can be said that it is a parallel development, algebra performance and HLT based teaching through MEGEDEP portal. The results obtained from the quantitative findings also support this. It was concluded that there were differences in the algebra achievement of the students of the teachers (T5, T4, T8) assigned to different development levels. However, differences were observed in student responses in the post-test parallel to the development levels of teachers. Only the students of the higher-level teacher were able to express the relationships between quantities with the general rule, usually by switching between representations with the $t-$ table. The students of the teachers assigned to the upper intermediate and low levels mostly gave incorrect or incomplete answers in the post-test. While most of the students of the teachers assigned to high and upper-intermediate levels to the questions in the post-test, both within the scope of algebraic expressions, answered correctly, most of the students of the teachers assigned to the middle level made mistakes due to arithmetic and operation knowledge. Similarly, it was observed that the students of this teacher made mistakes in the questions within the scope of equality-equation in the post-test, mostly due to misconceptions. This is due to the students' 
inaccurate and incomplete prior knowledge. As Linchevski and Herscovics (1994) stated, students' mistakes and failures in the field of algebra do not give information about their capacities. On the contrary, it gives a clue about how the teaching process should develop. In this context, it can be said that the teacher assigned to the middle level does not improve the teaching process effectively. The least improvement as a result of professional support based on HLT confirms this result.

There were two findings results in the study. One is that an upper-intermediate teacher (L2) is one of the classes whose students show the most improvement, and the other is that the students of the teacher with the highest level (L3) show the least improvement. The reason for this result may be that the high-level teacher has unfavourable socio-economic conditions for the students, and the students of the other teacher receive education in a rural school, while the other teacher's students receive advanced socio-economic education in a central school. Studies in the educational literature indicated that there is a strong positive relationship between the socioeconomic level of the student and academic achievement (Entwisle \& Alexander, 1995; Hoff, 2003).

As a result of the professional development carried out by modelling the predicted learning trajectories of the algebra learning field with the MEGEDEP project, teachers have begun to predict the misconceptions students may experience about the target achievement, to know what prior knowledge students should have about the subject, and to teach in a planned manner based on these. This development increased the quality and efficiency of teaching and positively affected students' success in algebra. From here, it was concluded that the teaching based on learning trajectories prepared on MEGEDEP generally had a positive effect on students' algebra success. In the model named TRIAD (Technology-Supported, Research-Based, Instruction, Assessment and Professional Development), which applied by Sarama et al. (2008) to kindergarten students, the professional development of teachers was supported and the use of education and technology to understand students' developmental progress or learning trajectories was emphasized. As a result of the research, it was determined that the mathematics achievement of the students in the TRIAD group was significantly higher than the students in the control group, and the model increased the quality of the mathematics environment and teaching in preschool classes. Other studies in the literature also show that modelling predictive learning trajectories is important for effective learning; It is claimed that it increases student success (Clements, Sarama, Spitler, Lange \& Wolfe; 2011; Wright, 2014; Wilson et al., 2013).

When other studies in the literature on teaching algebra were examined, it was seen that similar to the results of this study, algebra teaching using different methods and techniques increased student achievement. Studies advocate the realization of algebra teaching using different approaches to be successful in algebra. In this context, the results obtained support the literature (Pugalee, 2001; Hofmann \& Hunter, 2003; Witzel, 2005).

\subsection{Suggestions and Future Implications}

Since mathematics - especially algebra - progresses sequentially and gradually in a linear structure, it is thought that if the student cannot grasp any concept in the past, it will have difficulty in understanding the concepts in the preceding processes. For this reason, the more incomplete or incorrect the prior knowledge of the student, the more difficult it is to teach new concepts and to eliminate erroneous preliminary information. To overcome this situation, it is necessary to know the students' incomplete and erroneous prior knowledge in advance and to correct this in a long period. According to the results obtained from the research, teachers need to know in advance what the students should have in the field of algebra, the misconceptions, mistakes or difficulties they may experience. It is recommended that teachers carry out planned and scheduled teaching in line with this information. At this point, the HLT model can be regarded as a teaching tool and can be included in the teaching processes more frequently. To enrich their teaching processes with different teaching tools and to be informed about new developments, teachers can follow the literature on their fields and continue their professional development. Teachers can be provided 
with in-service or web-based training to support their professional development in their fields. Besides, encouraging studies can be conducted for teachers to make them continue postgraduate education.

Considering the positive development of teachers participating in the MEGEDEP project as a result of professional support from moderators who are experts in their fields, online web-based platforms can be made more widespread for similar purposes. In this way, teachers can find the opportunity to benefit from their knowledge and experience by constantly communicating with academicians. More recently, seminars on the professional development of teachers can be organized through online training that has increased due to COVID-19.

Finally, in this study, professional support to teachers was limited to as little as four weeks. However, it is not known how its effect will change in the long-term process. Therefore, another research can be carried out in a longer time frame and with different grade levels.

Acknowledgement. This research is supported by the Scientific and Technological Research Council of Turkey (TÜBITTAK) under SOBAG 1001 programme. The third author was affiliated at the Eskisehir Osmangazi University of Turkey when the project was carried out.

\section{References}

Akiba, M., \& Liang, G. (2016). Effects of teacher professional learning activities on student achievement growth. The Journal of Educational Research, 109(1), 99-110.

Akkan, Y., Baki, A., \& Çakıroğlu, Ü. (2011). Differences between arithmetic and algebra: Importance of prealgebra. Elementary Education Online, 10(3), 812-823.

Ball, D. L., Thames, M. H., \& Phelps, G. (2008). Content knowledge for teaching: What makes it special. Journal of Teacher Education, 59(5), 389-407.

Barbieri, C. A., Miller-Cotto, D., \& Booth, J. L. (2019). Lessening the load of misconceptions: Design-based principles for algebra learning. Journal of The Learning Sciences, 28(3), 381-417.

Bright, G. W., Bowman, A. H., \& Vacc, N. N. (1997). Teachers' frameworks for understanding children's mathematical thinking. In E. Pehkonen (Ed.), Proceedings of the 21st Conference of the International Group for the Psychology of Mathematics Education (pp. 105-112). Lahti, Finland: University of Helsinki.

Callaghan, M.N., Long, J. J., Van Es, E. A., Reich, S. M., \& Rutherford, T. (2018). How teachers integrate a math computer game: Professional development use, teaching practices, and student achievement. Journal of Computer Assisted Learning, 34(1), 10-19.

Carraher, D., Schliemann, A. D., \& Brizuela, B. M. (2005). Treating the operations of arithmetic as functions. Journal for Research in Mathematics Education, Monograph, 13. https://www.jstor.org/stable/30037729

Clarke, D., \& Hollingsworth, H. (2002). Elaborating a model of teacher professional growth. Teaching and Teacher Education, 18(8), 947-967.

Clements, D. H., Sarama, J., Spitler, M. E., Lange, A. A., \& Wolfe, C. B. (2011). Mathematics learned by young children in an intervention based on learning trajectories: A large-scale cluster randomized trial. Journal for Research in Mathematics Education, 42(2), 127-166.

Creswell, J.W. (2011). Educational research - planning, conducting and evaluating quantitative and qualitative research (4th Ed). Boston, MA: Pearson.

Darling-Hammond, L. (1997). Doing what matters most: Investing in Quality Teaching. National Commission on Teaching \& America's Future: New York, US.

Entwisle, D.R., \& Alexander, K.L. (1995). A parent's economic shadow: Family structure versus family resources as influences on early school achievement. Journal of Marriage and the Family, 57(2), 399-409.

Even, D., \& Ball, D.L. (Eds). (2010). The professional education and development of teachers of mathematics: The 15th ICMI Study. New York: Springer.

Falkner, K. P., Levi, L., \& Carpenter, T. P. (1999). Children's understanding of equality: A foundation for algebra. Teaching Children Mathematics, 6(4), 232-236.

Goos, M. (2020). Crossing boundaries: Fostering collaboration between mathematics educators and mathematicians in initial teacher education programmes. In Bailey et al. (Eds.) From Analysis to Visualization (pp. 141-148). Cham: Springer International Publishing. 
Hoff, E. (2003). The specificity of environmental influence: Socioeconomic status affects early vocabulary development via maternal speech. Child Development, 74, 1368-1378.

Hofmann, R. S., \& Hunter, W. R. (2003). Just-in-time algebra: a problem-solving approach including multimedia and animation. Mathematics \& Computer Education, 37(1), 55-62.

Hurst, C. (2016). Provoking contingent moments: Knowledge for 'powerful teaching' at the horizon. Educational Research, 59(1), 107-123.

Linchevski, L. \& Herscovics, N. (1994). Cognitive obstacles in pre-algebra. In J.P. da Ponte \& J.F. Matos (Eds.)Proceedings of the 18th Conference of the International Group for the Psychology of Mathematics Education, (pp. 176-183). Lisbon, Portugal: PME.

Miles, M. \& Huberman, M. (1994). Qualitative Data Analysis: An Expanded Sourcebook. London: Sage.

Ministry of National Education [MoNE]. (2018). Turkey's education vision 2023. https://2023vizyonu.meb.gov.tr/

Mojica, G. (2010). Preparing pre-service elementary teachers to teach mathematics with learning trajectories (Unpublished doctoral dissertation). North Carolina State University, USA.

Mokh, A. (2019). Mistakes made by students with logical connectives when solving equations and inequalities, and how teachers assess these mistakes. International Journal of Research in Education And Science, 5(2), 421-428.

Neubrand, M. (2018). Conceptualizations of professional knowledge for teachers of mathematics. ZDM Mathematics Education, 50(4), 601-612.

Prast, E. J., Van de Weijer-Bergsma, E., Kroesbergen, E. H., \& Van Luit, J. E. (2018). Differentiated instruction in primary mathematics: Effects of teacher professional development on student achievement. Learning and Instruction, 54, 22-34.

Pugalee, D. K. (2001). Algebra for all: The role of technology and constructivism in an algebra course for atrisk students. Preventing School Failure: Alternative Education for Children and Youth, 45(4), 171-176.

Rowland, T, Huckstep, P., \& Thwaites, A. (2005). Elementary teachers' mathematics subject knowledge: The knowledge quartet and the case of Naomi. Journal of Mathematics Teacher Education, 8(3), 255-281.

Sarama, J., Clements, D. H., Starkey, P., Klein, A., \& Wakeley, A. (2008). Scaling up the implementation of a pre-kindergarten mathematics curriculum: Teaching for understanding with trajectories and technologies. Journal of Research on Educational Effectiveness, 1(2), 89-119.

Sarama, J., DiBiase, A. M., Clements, D. H., \& Spitler, M. E. (2004). The professional development challenge in preschool mathematics. In D.H. Clements \& J. Sarama (Eds.) Engaging Young Children in Mathematics: Standards for Early Childhood Mathematics Education (pp. 415-446). Lawrence Erlbaum Associates Inc.: Mahwah, NJ.

Shulman, L.S. (1986). Those who understand: Knowledge growth in teaching. Educational Researcher, 15, 4-14.

Simon, M. A., \& Tzur, R. (2004). Explicating the role of mathematical tasks in conceptual learning: An elaboration of the hypothetical learning trajectory. Mathematical Thinking and Learning, 6(2), 91-104.

Simon, M.A. (1995). Reconstructing mathematics pedagogy from a constructivist perspective. Journal for Research in Mathematics Education, 26(2), 114-145.

Stephens, A. C. (2008). What "counts" as algebra in the eyes of preservice elementary teachers?. The Journal of Mathematical Behavior, 27(1), 33-47.

Tanışlı, D., \& Özdaş, A. (2009). The strategies of using the generalizing patterns of the primary school $5^{\text {th }}$ grade students. Educational Sciences: Theory and Practice, 9(3), 1485-1497.

Tanışli, D., Ayber, G., \& Turgut, M. (2018). Development of a combined test assessing sixth and seventh graders' mathematical competence of algebra. In E. Bergqvist, M. Österholm, C. Granberg, \& L. Sumpter (Eds.). Proceedings of the $42^{\text {nd }}$ Conference of the International Group for the Psychology of Mathematics Education (p. 170). Umea, Sweden: PME.

Tanışlı, D., Ayber, G., Köse, N., \& Turgut, M. (2018). Professional development through a web-based educational system: Opinions of middle school mathematics teachers. International Journal of Progressive Education, 14(6), 99-116.

Tanışlı, D., Köse, N., \& Turgut, M. (2019). Professional development through a web-based portal: The progress of mathematics teachers teaching algebra based on hypothetical learning trajectories. In U. T. Jankvist, M. van den Heuvel-Panhuizen, \& M. Veldhuis (Eds.), Proceedings of the Eleventh Congress of the European Society for Research in Mathematics Education (pp. 2741-2748). Utrecht, the Netherlands: Freudenthal Group \& Freudenthal Institute, Utrecht University and ERME. 
Thomas, M., \& Tall, D. (2001). The long-term cognitive development of symbolic algebra. International Congress of Mathematical Instruction (ICMI) Working Group Proceedings - The Future of the Teaching and Learning of Algebra, (pp. 590-597). Melbourne, Australia: ICMI.

Wilson, P. H., Mojica, G. F., \& Confrey, J. (2013). Learning trajectories in teacher education: Supporting teachers' understandings of students' mathematical thinking. The Journal of Mathematical Behavior, 32(2), 103-121.

Witzel, B. S. (2005). Using CRA to teach algebra to students with math difficulties in inclusive settings. Learning Disabilities: A Contemporary Journal, 3(2), 49-60.

Wright, V. (2014). Towards a hypothetical learning trajectory for rational number. Mathematics Education Research Journal, 26(3), 635-657.

Yildırım, A. (2013). Teacher education research in Turkey: Trends, issues and priority areas. Education and Science, 38(169), 175-191.

Zembat, I.O. (2016). Mathematics teaching cycle and hypothetical learning trajectories. In E. Bingolbali, S. Arslan and I.O. Zembat (Eds.), Theories in Mathematics Education, (pp. 509-518). Ankara, Turkey: Pegem Akademi.

Zielinski, S. F. (2017). From no to yes: the impact of an intervention on the persistence of algebraic misconceptions among secondary school algebra students (Unpublished doctoral dissertation). Northeastern University, Boston. 